\title{
Aluzje literackie w teologicznej ocenie działań arcykapłana Szymona w 1 Mch 14,5
}

\author{
Literary allusions in the theological evaluation of the activities of Simon, \\ the High Priest in 1 Macc 14:5
}

\author{
JANUSZ NAWROT \\ Uniwersytet im. Adama Mickiewicza w Poznaniu \\ jannaw@amu.edu.pl \\ ORCID: 0000-0002-2498-5081
}

\begin{abstract}
Each biblical book reveals its theological message in a very diverse literary way. The analyzed verse of 1 Macc 14:5, similarly to the other verses of the book, was written in the form of a cento, a well-known literary genre used in antiquity. This cento combines expressions in the verses of the earlier Old Testament books and builds its own theological message. Thus an intertextual allusion is built upon the complete textual conformity of the verses from $1 \mathrm{Macc}$ and the cited expressions. The literary context is crucial for the choice of the allusion. This context influences the carrying theological capacity of the verses and what they bring in the construction of a new message. The allusions reveal the actual meaning of the described events in a theological context. The revelation of the hagiographer's intention enables the reader to accurately evaluate the conduct of particular characters, in this case Simon Maccabaeus, the high priest of Jews in the times of the Maccabean revolt.
\end{abstract}

KEYwORDs: Simon Maccabaeus, the Maccabean revolt, The First Book of Maccabees, Old Testament, cento, intertextual allusion

SŁowA KLuczowe: Szymon Machabeusz, powstanie machabejskie, Pierwsza Księga Machabejska, Stary Testament, centon, aluzja intertekstualna

E

gzegeza tekstu Pierwszej Księgi Machabejskiej wskazuje, że hagiograf -w kompozycji swego dzieła posłużył się licznymi sposobami budowania aluzji nawiązujących do starannie dobranych, wcześniejszych tekstów biblijnych ${ }^{1}$. W wydanym niedawno II tomie komentarza do tej księgi starano się wykazać, że znaczna większość jej materiału została przedstawiona przez hagiografa właśnie w ten sposób ${ }^{2}$. Zabieg aluzji i jej rozmaite formy są zatem jednym z ważnych kluczy interpretacyjnych dla tego natchnionego tekstu. Prezentowany artykuł po-

1 Swą właściwą funkcję ukrytej krytyki postępowania przywódców powstania machabejskiego aluzja zaczęła pełnić - jak się wydaje - od momentu utraty świątyni przez Judę Machabeusza na rzecz armii seleuckiej (1 Mch 6,49.53), J. Nawrot, „Dlaczego oni zwyciężają? Teologiczna ocena judejskiej kampanii Antiocha V Eupatora w 1 Mch 6,47-54”, SG 31 (2017) 90-94, 98-103.

2 J. Nawrot, Pierwsza Księga Machabejska. Rozdziały 6,17-16,24 (NKB.ST 14/2; Częstochowa: Edycja Świętego Pawła 2020) 83-1105. Komentarz ten stanowi - jak się wydaje - pierwszą próbę 
dejmuje tę kwestię, używając właściwego nazewnictwa, którego zabrakło w komentarzu, oraz pokazuje odmiany i funkcjonowanie aluzji na wybranym przykładzie 1 Mch 14,5. Werset ten jest reprezentatywny niemal dla całości tekstu natchnionego ${ }^{3}$. Tytułem przykładu niech będzie stwierdzenie, że tylko w najbliższym kontekście 14,4-15 można wyliczyć aż 51 tych aluzji ${ }^{4}$.

Aby odkryć w czytanym (i badanym) tekście zabieg aluzji, należy przyjąć istnienie tego, co w literaturoznawstwie definiuje się powszechnie jako intencję autora. Słownikowo mówiąc, chodzi o ,skierowanie umysłu ku czemuś (...), racja jakiegoś działania, nieosiągnięty jeszcze cel jakiegoś dążenia"s. Na gruncie literaturoznawczym badacze rozróżniają intencję wirtualną, wyrażającą się pytaniem: „co autor chciał powiedzieć?”. By tę intencję dać poznać, autor czasem sam podaje pewne wytyczne dla jej poprawnego zrozumienia przez czytelnika. Natomiast do intencji aktualnej przyporządkowane są pytania: czego czytelnik domyśla się, „co autor miał na myśli, wypowiadając coś?” lub: „,o w istocie (naprawdę) tu przez to powiedział?”'. Najważniejsze wówczas staje się zrozumienie przez czytelnika intencji autora, a poprawność tego zrozumienia wyrazi się w możliwie największym pokryciu się obu intencji: gdy to, co zamierzone przez autora zostanie właściwie, czyli zgodnie z jego intencją odczytane przez odbiorcę. Aktualna intencja autora oddziałuje decydująco na zrozumienie tekstu, nie będąc wobec niego czymś zewnętrznym ani uprzednim. Jest to intencja operacyjna, przejawiająca się w tekście i poprzez tekst oraz tekstualnie ugruntowana $^{7}$. Stosowanie aluzji jest zatem rezultatem celowego działania autora, procesem w pełni świadomym, chociaż nie wymienia się tu wprost imienia przywoływanego aluzyjnie autora innego dzieła czy też bohatera, ani nie podaje się miejsca zaczerpnięcia kontekstu czy też sytuacji, na które stosujący aluzję autor się powołuje. Analitycy zagadnienia zwracają także uwagę, że tworzący aluzję zakłada, że adresat wygłaszanej mowy lub zapisanego tekstu zna okoliczności powstania aluzji, a ta wiedza daje mu sygnał odsyłający go do samego jej przedmiotu. Twórca aluzji zakłada, że odbiorca zinterpretuje ją poprawnie dzięki swojej uprzedniej wiedzy lub dzięki odnalezieniu odpowiednich narzędzi pozwalających tego dokonać. Gdyby nie zamierzał on celowo dotrzeć do czytelnika ze swoim aluzyjnym komunikatem, czyli bez tej ,praktycznej intencji”, nie można

podejścia do tekstu natchnionego w ten właśnie sposób. Większość dotychczasowych opracowań traktowała księgę bardziej jako dokument historyczny, nie zaś dzieło teologiczne.

3 W sposób podsumowujący, choć jeszcze bez wzmiankowania aluzji, kwestia ta została zaprezentowana w Nawrot, Pierwsza Ksiega Machabejska. Rozdziaty 6,17-16,24, 1143-1148.

4 Nawrot, Pierwsza Księga Machabejska. Rozdziały 6,17-16,24, 891-911.

5 A. Podsiad - Z. Więckowski (red.), Mały stownik terminów i pojęć filozoficznych dla studiujących filozofię chrześcijańską (Warszawa: Instytut Wydawniczy Pax 1985) 162.

6 D. Szajnert, „Intencja i interpretacja”, PaL 91/1 (2000) 27.

7 Szajnert, „Intencja i interpretacja”, 28. Szerokie studium o intencji w dziele literackim poczynił także Göran Hermerén („Intencja a interpretacja w badaniach literackich”, PaL 68/4 [1977] 353-381). 
byłoby powiedzieć, że świadomie stosuje zabieg aluzji ${ }^{8}$. Nie trzeba dodawać, że intencja autora natchnionego posiada dla lektury Biblii absolutnie pierwszorzędne znaczenie $(D V 12)^{9}$. Aluzja nie należy do poziomu rodzaju literackiego danego tekstu, lecz jest pewnego rodzaju zabiegiem technicznym, świadomie przez autora stosowanym by wyrazić myśli zawarte $\mathrm{w}$ danym dziele literackim, w tym przypadku w księdze biblijnej. Wprowadza ona dzieło twórcy w sferę szeroko pojętych relacji intertekstualnych. W Pierwszej Księdze Machabejskiej aluzje zostały użyte w celu ukazania wydarzeń z okresu powstania żydowskiego przeciw monarchii seleuckiej w świetle teologii znanych autorowi ksiąg Starego Testamentu. Hagiograf dokonał tego przez nawiązanie zarówno do tekstów ksiąg kanonicznych, w których dominuje narracja historyczna, jak i do ksiąg prawodawczych, a nawet mądrościowych, obecnych w Septuagincie, choć w różnym natężeniu i częstości odniesień. Egzegeza wersetów księgi w dostępnej wersji greckiej świadczy, że autor korzystał z tekstów ksiąg proto- jak i deuterokanonicznych Septuaginty, z wyjątkiem Drugiej Księgi Machabejskiej oraz Księgi Mądrości, jeszcze wówczas nienapisanych ${ }^{10}$. Nic natomiast nie można powiedzieć o tekście hebrajskim Pierwszej Księgi Machabejskiej, którym już dziś nie dysponujemy ${ }^{11}$.

Najważniejszym argumentem przemawiającym za intencjonalnością autora jest wewnętrzna spójność teologiczna zarówno w treści pojedynczego wersetu, jak i we fragmencie, do którego on przynależy. Musi się ona pojawić także w obrębie samej księgi, a wreszcie być zgodna z całością orędzia starotestamentowego. Poddany analizie werset 1 Mch 14,5 stanowi szczególny przykład różnora-

8 S. Przybyszewski, „Semantyczna i syntaktyczna analiza leksemu aluzja”, Prace Językoznawcze 10 (2008) 195-196.

9 Dokumenty Kościoła postulują poprawne odkrywanie rozlicznych gatunków literackich, poprzez które można dojść do odszukania właściwej intencji hagiografów. Jest to najbardziej generalny postulat egzegezy. Badanie sposobów stosowania aluzji - tam, gdzie mogą one występować - bezsprzecznie wchodzi w skład całego procesu ustalania, w jaki sposób hagiografowie przekazywali treść natchnioną w swoich dziełach. Stanowią one bowiem część tego, co nazywamy dziś egzegezą wewnątrzbiblijną, gdy teksty wyjaśniają się przez siebie. Jeśli czynią to w sposób najbardziej wyraźny pod kątem teologicznym, badanie aluzji umieszcza je mocniej na płaszczyźnie literackiej, jako zabieg stylistyczny autorów natchnionych. Końcowym jednak efektem tego działania w księgach jest niewątpliwie osiągnięcie celu teologicznego - ukazania zbawczego orędzia danego fragmentu oraz całej księgi biblijnej, której jest on częścią.

10 Tabela samych tylko tekstów ksiąg deuterokanonicznych, do których autor natchniony zastosował aluzje (niemal 250), została podana w Nawrot, Pierwsza Księga Machabejska. Rozdziały 6,17-16,24, 1136-1142. Zapożyczenia terminologiczne wersetów ksiąg protokanonicznych są zbyt liczne, by je wszystkie zacytować. Czytelnik odnajdzie je explicite w lekturze poszczególnych wersetów Pierwszej Księgi Machabejskiej.

11 Suponowane jego istnienie wnioskuje się z zapisu św. Hieronima w jego Prologus Galeatus, czyli we wstępie do komentarza do Ksiąg Samuela i Królewskich, oraz niewątpliwych hebraizmów obecnych w tekście greckim Pierwszej Księgi Machabejskiej. J. Nawrot, Pierwsza Księga Machabejska. Rozdziały 1,1-16,16 (NKB.ST 14/1; Częstochowa: Edycja Świętego Pawła 2016) 184-190. 
kich sposobów wykorzystania aluzji obecnych w całej księdze ${ }^{12}$. Zastosowanie aluzji w badanym wersecie będzie można lepiej zrozumieć, jeśli przypomni się założenia teorii aluzji intertekstualnej oraz centon, jako gatunek literacki, którym - jak się okaże - posłużył się hagiograf.

\section{Aluzja literacka - kilka principiów}

Warto na początku wspomnieć podstawową różnicę między cytatem a aluzją, by skupić się właśnie na tej drugiej. Językoznawca Jan Grzenia ukazuje tę różnicę w sposób bardzo wyraźny. Przytoczenie tekstu w formie cytatu to przytoczenie dosłowne tekstu, do którego nawiązuje tekst przywołujący. Natomiast aluzja przekształca tekst źródłowy, czyniąc związek intertekstowy niejednoznacznym, ale wyrazistym ${ }^{13}$. Ważną uwagę podaje także Sebastian Przybyszewski, pisząc o stosowaniu aluzji jako działaniu celowym lub bardziej jako działaniu zdradzającym intencje autora. Obydwa te procesy Przybyszewski opisuje jako postępowanie w pełni świadome. Dla potrzeb niniejszego opracowania zaakcentować należy zwłaszcza brak wyraźnego przytoczenia konkretnego imienia jakiejś osoby, nazwy rzeczy, o którą chodzi, czy też przywołania explicite sytuacji, na którą piszący chce się powołać. Twórca aluzji zakłada jednak wyraźnie jakąś, choćby minimalną wiedzę adresata na temat tego, co jest związane z obiektem aluzji, dając mu sygnał odsyłający do jej obiektu ${ }^{14}$.

Joseph M. Pucci podaje kolejne wskazówki dla poprawnego rozumienia aluzji literackiej, przytaczając zasadnicze jej cechy:

a) zapożyczanie związane $\mathrm{z}$ aluzją literacką zawsze obejmuje język wspólny dla dwóch dzieł literackich;

12 Przykładem takim może stać się np. werset 1 Mch 8,19, nawiązujący celowo do 1 Krl 19,7 i Joz 9,13

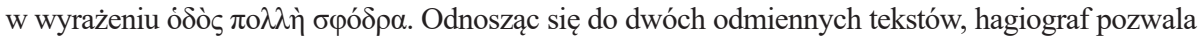
sobie na ocenę postępowania Eliasza (tekst pierwszy) oraz podstępnej delegacji Gabaonitów (tekst drugi), w różnym świetle i pod różnym kątem wydobywając te lub inne czynniki, zawarte w motywacji lub celu ich działania. Warunkiem prawidłowego odczytania tego typu aluzji jest absolutna zgodność treściowa i teologiczna między nimi, chociaż kontekst wydarzeń może być nie tylko różny, lecz całkowicie przeciwstawny sobie. Takie nawiązanie do dwóch odmiennych tekstów występuje również w omawianym obecnie wersecie Pierwszej Księgi Machabejskiej. O możliwości takiego wieloźródłowego nawiązania mówi Jan Grzenia („,Funkcje aluzji literackiej na przykładzie poezji Jarosława Marka Rymkiewicza”, Język Artystyczny 7 [1990] 88-89).

13 J. Grzenia, „Cytat a aluzja literacka”, Z problemów współczesnego języka polskiego (red. A. Wilkoń - J. Warchala) (Katowice: Uniwersytet Śląski 1993) 111.

14 Przybyszewski, „Semantyczna i syntaktyczna analiza”. Niektórzy analitycy problemu akcentują to jeszcze mocniej pisząc: „Pośród różnych form wpływów jedynie o aluzji literackiej można mówić jako o »rodzaju środka artystycznego«, co przecież implikuje warunek świadomości i celowości użycia” (Grzenia, „Funkcje aluzji literackiej”, 80). 
b) zapożyczenie to jest konkretne i możliwe do zweryfikowania;

c) zapożyczenia tego nie można oszacować, tzn. wyliczyć z góry jego cech ${ }^{15}$.

Podobne uwagi podaje także Konrad Górski, ustalając warunki aluzji literackiej: odniesienie do powszechnie znanego utworu, operowanie podobną lub wręcz identyczną tematyką oraz kształtowanie relacji obu tekstów jako opozycji jednego do drugiego ${ }^{16}$.

Możliwość poprawnego odczytania intencji autora, jako warunek konieczny zastosowania aluzji, akcentuje zwłaszcza Ziva Ben-Porat, przedstawiając cztery etapy, przez które musi przebrnąć czytelnik identyfikujący i interpretujący aluzję w czytanym tekście ${ }^{17}$. Na pierwszym etapie rozpoznaje on znacznik, który nawiązuje do odrębnego tekstu. W przypadku tekstu literackiego znacznik ów to słowna konstrukcja łącząca tekst przywołujący i przywoływany, choć niekoniecznie pojawia się ona w formie dosłownej. Na etapie drugim dochodzi do identyfikacji przywołanego tekstu, zawierającego ów znacznik, chociaż odniesienie do wcześniejszego tekstu nie jest od razu oczywiste. Następnie czytelnik modyfikuje własne rozumienie znacznika w tekście przywołującym (czyli późniejszym) na podstawie jego właściwej interpretacji w tekście przywołanym (czyli wcześniejszym). Wzajemne oddziaływanie na siebie obu tekstów powoduje nowe zrozumienie znacznika. Nie byłoby to możliwe, gdyby czytelnik pozostał na poziomie wyłącznie tekstu przywołującego. Dopiero owa modyfikacja znacznika pozwala stwierdzić obecność aluzji. Wówczas uwaga czytelnika przesuwa się od samego znacznika do innych tekstów, które go zawierają, a przez to ta intertekstowa lektura staje się jedną powiązaną całością. Wreszcie dalsza lektura to szersze uwzględnienie cech obu tekstów, wybiegające poza sam znacznik.

\section{Centon jako gatunek literacki użyty w Pierwszej Księdze Machabejskiej}

Michał Głowiński wydaje się szczególnie trafnie nazywać typ aluzji, która zostanie poniżej zaprezentowana, kolażem lub montażem składającym się z cytowania pochodzącego z rozmaitych tekstów literackich. Dzięki takiemu sposobowi stosowania aluzyjności werset przypomina centon, czyli utwór literacki skompilowany w całości z cytatów innych utworów, najczęściej znanych, łatwo rozpo-

15 J.M. Pucci, The Full-Knowing Reader. Allusion and the Power of the Reader in the Western Literary Tradition (New Haven, CT: Yale University Press 1998) 30-32.

16 K. Górski, „Aluzja literacka”, Problemy teorii literatury (red. H. Markiewicz) (Wrocław - Warszawa-Kraków: Ossolineum 1987) I, 315.

17 Z. Ben-Porat, „,The Poetics of Literary Allusion”, PTL 1 (1976) 110-111. 
znawalnych i upodabniający się tym samym do brikolażu ${ }^{18}$. Jeśli chodzi o zastosowane zwroty językowe, centon jest całkowitą pochodną dzieł wcześniejszych. Paradoksalnie jest to jednak dzieło całkowicie oryginalne pod względem formalnym, ma własną, oryginalną koncepcję oraz własną, nową treść zawartą w poszczególnych wersetach. Warto o tym wspomnieć, ponieważ dla wielu badaczy wyjątkowość centonu polega właśnie na jego absolutnej (sic!) pochodności ${ }^{19}$.

Autor Pierwszej Księgi Machabejskiej czyni - jak się wydaje - dokładnie to, co starożytny poeta i retor Auzoniusz napisał o własnym centonie: de inconexis continuum, de diversis unum, (...) de alieno nostrum, ,z tego, co niespójne połączenie, z różności - jedność, (...) z obcego - własność" ${ }^{20}$. Łaciński poeta scharakteryzował dalej centon jako rodzaj „lekkiej muzy”, z którą obchodzi się na podobieństwo gry, a jej celem jest połączenie różnych znaczeń, tak, aby części dowolnie dobrane z różnych źródeł wydawały się spójne i naturalnie ze sobą powiązane. Ma to być jednak na tyle ścisłe, by elementów sobie obcych nie dzieliła pusta przestrzeń, by nie ukazywały naprężenia, by to, co ponadto i to co, nieco naciągane nie przeważało nad tym, co spaja; i na koniec, by elementy ściśle ze sobą połączone nie ujawniały swej odrębności, te zaś, które są powiązane luźno, nie miały między sobą przeskoków ${ }^{21}$. Dzisiaj najbliższym może sposobem tworzenia centonu byłaby gra w puzzle, dostarczająca urywków tekstu, jak kawałków obrazu, który kształtuje się w miarę dokładania nowych elementów. Takie literackie puzzle można złożyć już na poziomie wersetu, potem dłuższego fragmentu, by skończyć na całej księdze, która w ten sposób staje się jednym, wielkim centonem. Badacze pochylający się nad omawianą problematyką zwracają uwagę na konieczność bardzo dobrej znajomości przez czytelnika dzieł, do których nawiązuje centon, ponieważ w przeciwnym razie nie jest on w stanie zło-

18 M. Głowiński, „O intertekstualności”, PaL 77/4 (1986) 84.

19 S. McGill, Virgil Recomposed. The Mythological and Secular Centos in Antiquity (Oxford - New York: Oxford University Press 2005) 23. W niniejszym tekście został wyłączony element, który Auzoniusz określił jako de seriis ludicrum, dosł. ,z powagi - grę”. Autor Pierwszej Księgi Machabejskiej nie miał z pewnością intencji zapraszania czytelnika do zabawy w łamanie sobie głowy nad znaczeniem tego, co napisał. Swoisty ,centon machabejski” pełni rolę wyłącznie służebną wobec przekazu zamierzonej treści i nie powstał jako poemat sam dla siebie.

20 Auzoniusz, Cento Nuptialis, praef. 20. Szerokie omówienie problematyki centonu w: A. Rondholz, The Versatile Needle. Hosidius Geta's Cento "Medea" and Its Tradition (Berlin - Boston, MA: De Gruyter 2012) 17-40. O strukturze poetyckiego centonu, R. Lamarcchia, „Metro e ritmo nella Medea di Osidio Geta", SIFC 30 (1958) 175-206.

21 W ten sposób interpretuję sens wypowiedzi poety: Hoc ergo centonis opusculum ut ille ludus tractatur, pari modo sensus diversi ut congruant, adoptiva quae sunt ut cognata videantur, aliena ne interluceant, arcessita ne vim redarguant, densa ne supra modum protuberent, hiulca ne pateant (Cento Nuptialis, praef. 37-40). Scott McGill (Virgil Recomposed, 20-21) zauważa tu bliskość z grą łamigłówkową, zwaną (o)stomachion, czyli 14 kawałków kości, które trzeba było odpowiednio zestawić; zob. także S.S. Cullhed, Proba the Prophet. The Christian Virgilian Cento of Faltonia Betitia Proba (Leiden - Boston, MA: Brill 2015) 137-145. 
żyć samodzielnie całej układanki i nie zrozumie przesłania kryjącego się w tym tekście-mozaice ${ }^{22}$.

\title{
3. 1 Mch 14,5: kontekst i analiza wstępna
}

Werset $\mathrm{w}$ wersji oryginalnej oraz dosłownym tłumaczeniu brzmi następująco:

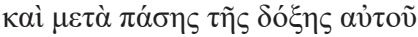

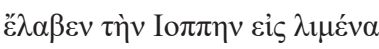

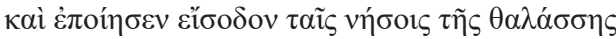 \\ „Z całym swym splendorem \\ zdobył Jaffę na port \\ i uczynił wejście wyspom morza".
}

Fragment ten należy do bliższego kontekstu wersetów 4-15, tworzących formalnie panegiryk na cześć arcykapłana Szymona Machabeusza, który objął władzę nad prowincją judejską w czasach powstania machabejskiego po śmierci swego brata Jonatana. Cały hymn pochwalny, rozdzielający opowieść o dwu różnych epizodach wojny o niepodległość, można tematycznie podzielić następująco:

a) wprowadzenie, będące zarazem ogólną oceną rządów Szymona (w. 4);

b) szczegółowe działania Szymona zasługujące na pochwałę

(ww. 5-7.10-11a.14-15):

- zdobycie Jaffy dla Judei (w. 5),

- powiększenie terytorium prowincji wraz z objęciem władzy (w. 6),

- zdobycie niewolników, opanowanie twierdz w Gezer, Bet-Sur i Jerozolimie (w. 7),

- zaopatrzenie dla miast $\mathrm{i}$ ich odbudowa, połączone ze wzrostem sławy Szymona (w. 10),

- zapewnienie pokoju mieszkańcom (w. 11a),

- działania na rzecz sprawiedliwości w kraju (w. 14),

- działania na rzecz uświetnienia kultu świątynnego (w. 15);

c) opis sytuacji w kraju za czasów zwierzchnictwa Szymona (ww. 8-9.11b-13):

- spokój i dobrobyt w kraju (w. 8),

- szczęście i duma mieszkańców miast (w. 9),

22 M. Okáčová, „Centones. Recycled Art Or The Embodiment of Absolute Intertextuality?”, http:// www.kakanien.ac.at/beitr/graeca_latina/MOkacova1.pdf [dostęp: 18.06.2020]. 
- powszechna radość w kraju (w. 11b),

- odpoczynek i spokój we własnych dobrach ziemskich (w. 12),

- wypędzenie wszystkich nieprzyjaciół z ziemi judejskiej i wolność od najazdów z zewnątrz (w. 13).

Powyższy fragment (ww. 4-15) wylicza zasługi arcykapłana na rzecz swego ludu. By poprawnie odczytać intencję, z jaką został on napisany, trzeba wziąć pod uwagę rzeczywiste zdanie hagiografa o arcykapłanie Szymonie i jego polityce, od początku krytyczne i coraz bardziej negatywne. Jeśli tak zwany „czytelnik naiwny" nie wgłębi się w terminologię, którą zastosował autor natchniony, łatwo ulegnie złudzeniu, że jest on niemal bezrefleksyjnym chwalcą cnót swego bohatera, widzącym w nim wyłącznie zalety wiodące do samych sukcesów. Nawet Bóg zdaje się wspierać Szymona w każdym posunięciu, doprowadzając go do szczytu popularności pośród ludu i do zdobywania niepodważalnych zasług na drodze ku trwałej niepodległości. Nawet tak świetny badacz historii tego okresu historii Izraela, jak Jonathan Goldstein, nie zauważył rzeczywistego wydźwięku tego panegiryku, który w swej strukturze powierzchniowej wygląda jak ciąg komplementów idealizujących Szymona, podczas gdy odczytany intertekstualnie kryje zupełnie inną treść. Trudno bowiem byłoby zrozumieć autora natchnionego, gdyby z wcześniejszej, zawoalowanej, ale stanowczej krytyki postępowania arcykapłana $(13,9.21$.27-30.34a.35-42.44-53) przeszedł tak gładko do hiperbolicznych pochwał. Dlatego z teologicznego punktu widzenia gorliwość Szymona ocenić należy jako zewnętrzną i pozorną.

W wersecie 5 autor pisze, że zdobycie i utrzymanie Jaffy to jeden ze strategicznych celów Szymona jako wodza powstania i przywódcy całego kraju. Dostęp do morza gwarantował wolny i łatwiejszy handel, niezależny od opłat, ceł i poborów wynikających z tranzytowego przewożenia towarów przez tereny innych państw i krain. Dla Szymona było to ważne również z tego powodu, że otaczające Judeę krainy były w pełni kontrolowane przez nieprzyjacielskie wojska imperium seleuckiego. Ponadto ze względu na ukształtowanie terenu Judei, pokrytej w znacznej większości górami i wyżynami, transport towarów stanowił nie lada wyzwanie. Znakomitym tego dowodem jest apokryficzny tekst 1 Ezd 5,53, w którym mowa jest o tym, że przez port ( $\lambda u \mu \eta ́ v)$ w Jaffie sprowadzano materiały na odbudowę świątyni w czasach powrotu Żydów z niewoli babilońskiej pod wodzą Zorobabela ${ }^{23}$. Dotyczy to - może w mniejszym stopniu, ale także - czasów współczesnych, dlatego wiele państw zabiega o dostęp do morza i budowę własnych portów. Nie dziwi więc zapobiegliwość arcykapłana w dziedzinie podniesienia strategicznych i ekonomicznych walorów swojego

23 Szerokie omówienie księgi wraz z prezentacją i analizą tekstu M. Wojciechowski (tł. i red.), Apokryfy z Biblii greckiej. 3 i 4 Księga Machabejska, 3 Księga Ezdrasza, oraz Psalm 151 i Modlitwa Manassesa (RSB 8 - Warszawa: Vocatio 2001) 210, 259. 
kraju. Dla ludu żydowskiego, dostrzegającego perspektywiczne myślenie arcykapłana, jego umiejętności strategicznego działania i talent organizacyjny musiały być ważnym elementem zaufania i powszechnej akceptacji społecznej, okazywanych działaniom tego zwierzchnika ludu.

\section{Analiza intertekstualna 1 Mch 14,5}

Po dokonanej analizie wstępnej wersetu możemy obecnie przejść do szczegółowego zbadania przywołanego tu przykładu, jakim jest omawiany werset. Od razu trzeba zaznaczyć, że nie jest on przykładem wyczerpującym wszelkie sposoby czynienia aluzji w księdze. W jaki zatem sposób hagiograf przeprowadza swe aluzje w omawianym wersecie Pierwszej Księgi Machabejskiej?

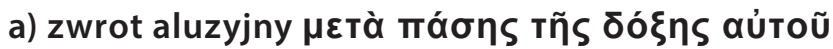

Przykładem aluzji powstałej poprzez zastosowanie całego zwrotu brzmiącego tak samo zarówno w tekście przywołującym, jak i przywoływanym jest konstrukcja

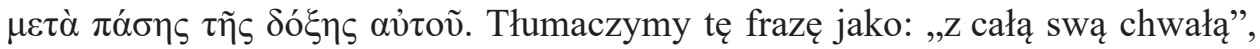
„W całej swej chwale" lub „poprzez całą swą chwałę"24. Czytelnik od razu zauważa użycie konstrukcji wyraźnie naddanej w stosunku do całości wypowiedzi. Pole semantyczne samego wersetu pozwala zupełnie spokojnie pominąć ów zwrot bez straty zawartych w nim pozostałych wiadomości.

Otóż cały ten zwrot znajduje się także w innym tekście - w Dn 4,29 [LXX]; Dn 4,26 [BH] - jedynym w Biblii greckiej:

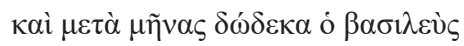

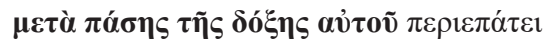

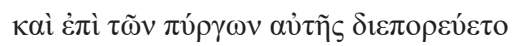

„A po dwunastu miesiącach król (Nabuchodonozor) po murach miasta

z calym swym splendorem przechadzał się

i doszedł aż do jego wież".

Autor Pierwszej Księgi Machabejskiej korzystał celowo z wersji greckiej, dłuższej od hebrajskiej Dn 4,26 [BH]. W tekście masoreckim Księgi Daniela brakuje słów o dojściu króla Nabuchodonozora do wież umacniających mury oraz o motywach jego pychy. Fakt, że królewska $\delta o ́ \xi \alpha$ powinna zostać zrozu-

24 A. Bailly, Dictionnaire grec-français, wyd. 26 (Paris: Hachette 1963) 1258. 
miana właśnie jako zewnętrzny przejaw pychy władcy, wynika z Dn 4,30 [LXX] (Dn 4,27 [BH]), zawierającego opis podziwu, w jaki król wpadł na widok piękna zbudowanego przez siebie miasta, mającego stanowić wyraz jego potęgi i przynosić chlubę jego majestatowi. W tekście tego wersetu grecki autor aż 4 razy pokazał moment królewskiej pychy w zwrotach: ,ja zbudowałem - dom królestwa mojego - sile mojej potęgi - ku chwale mojego majestatu", co spowodowało nagłą reakcję płynącą z nieba, ponieważ swoim samochwalstwem przekroczył dopuszczalną granicę i zamiast miłosierdzia sprowadził na siebie gniew Boga ${ }^{25}$.

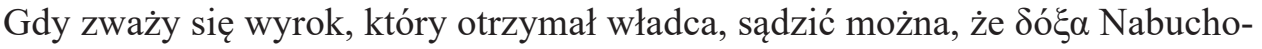
donozora została oceniona jako pycha przez samego Boga. Decyzję o ukaraniu pysznego monarchy podejmuje On natychmiastowo i natychmiastowo też wykonuje ów wyrok (Dn 4,31-33 [LXX]; Dn 4,28-30 [BH])26. Władca nie zauważył bowiem, że do swej potęgi doszedł dzięki miłosiernemu wsparciu Boga, który dodatkowo dał mu jeszcze rok na żal, pokutę i dokonanie poprawy życia. Zostało to Nabuchodonozorowi ukazane poprzez niepokojący go sen (Dn 4,10-18 [LXX]; Dn 4,7-15 [BH]) i poprzez wyjaśnienie, jakiego Daniel udziela królowi (Dn 4,19-27 [LXX]; Dn 4,16-24 [BH]). Monarcha nie wykorzystał tego czasu na pokutę i sen się całkowicie spełnił (Dn 4,31-33 [LXX]; Dn 4,28-30 [BH]) ${ }^{27}$.

Pewną wątpliwość w prawdopodobieństwo zapożyczenia przez autora aluzji tego właśnie tekstu Księgi Daniela mogłoby zasiać pytanie, czy w momencie tworzenia tekstu Pierwszej Księgi Machabejskiej istniała już grecka wersja Księgi Daniela, której czas powstania oblicza się generalnie na początek I w. przed Chr. Z badań krytycznych wynika jednak, że tzw. starogrecka wersja rozdziałów 4-6 księgi istniała zapewne wcześniej i niezależnie od całego późniejszego jej korpusu obecnego w Septuagincie ${ }^{28}$. Tę wersję lub jej późniejsze pochodne mógł znać już autor Pierwszej Księgi Machabejskiej i z powodzeniem ją stosować. Niektórzy komentatorzy przyjmują wprost możliwość zapożyczeń w tej księdze z innych tekstów greckiej wersji Księgi Daniela, stawiając tezę o porównywalnym czasie powstania obu dzieł ${ }^{29}$.

25 J. Phillips, Exploring the Book of Daniel. An Expository Commentary (JPCS; Grand Rapids, MI: Kregel Publications 2004) 79.

26 M. Parchem, Księga Daniela (NKB.ST 26; Częstochowa: Edycja Świętego Pawła 2008) 352-357. Możliwość interpretacji opisywanych fragmentów Księgi Daniela jako reminiscencji życia nie Nabuchodonozora, lecz późniejszego od niego Nabonida nie mają tu większego znaczenia z racji teologicznego, a nie historycznego podejścia hagiografa do tekstu Księgi Daniela; L.F. Hartman - A.A. Di Lella, The Book of Daniel. A New Translation with Introduction and Commentary (AncB 23; New York et al.: Doubleday 2005) 178-179.

27 Por. m.in. egzegezę Stephena R. Millera (Daniel. An Exegetical and Theological Exposition of Holy Scripture [NAC 18; Nashville: Broadman \& Holman 1994] 130-142).

28 R.T. McLay, "The Old Greek Translation of Daniel IV-VI and the Formation of the Book of Daniel", VT 55/3 (2005) 318-319.

29 Tak czynią m.in. Louis F. Hartman i Alexander A. Di Lella (The Book of Daniel, 78). Nawet jeśli trudno zgodzić się z tezą autorów o czasie powstania Pierwszej Księgi Machabejskiej, z cezurą 


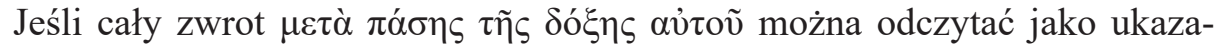
nie pychy królewskiej, to można chyba uznać, że sąd nad Szymonem Machabeuszem właśnie się dokonał. Według intertekstualnego odczytania znacznika, którym jest cała ta konstrukcja werbalna, wódz powstania całkowicie zapomniał, dzięki komu doszedł do obecnego splendoru swej władzy. Zdradzając niejako Boga, szybko zaczął wszelkie dokonania i zdobycze Izraela przypisywać sobie (1 Mch 13,9.11.29.51-52). Dlatego nadejdzie czas, gdy - podobnie do władcy babilońskiego - zostanie on pozbawiony swych zasług i wszystkiego, co osiągnął (1 Mch 13,37-41; 14,4-7.10-15), choć na razie nadal pnie się po szczeblach własnej pychy i dumy z coraz to nowych sukcesów. Czas jego błyskotliwej kariery będzie jednak bardzo krótki.

\section{b) dis legomenon: $ı \Perp \mu \varepsilon ́ v a$}

Niemal nigdy jeden termin zawarty w tekście nie powinien być uznawany za aluzję do innego tekstu, ponieważ znacznik jest wówczas zbyt słaby, a możliwych odniesień jest zbyt wiele. Trudno bowiem, dysponując jednym tylko słowem, wnosić, do którego z możliwych wcześniejszych tekstów odwoływać by się miała domniemana aluzja. Inaczej ma się sprawa, gdy odwołanie następuje do miejsca jedynego w całej Biblii greckiej. W badanym przez nas tekście Pierwszej Księgi Machabejskiej chodzi bowiem o accusativus $\lambda \mu \mu \varepsilon ́ v \alpha$, ,port, przystań”. Otóż słowo to to dis legomenon w kanonicznym tekście Septuaginty ${ }^{30}$. A zatem autor omawianej księgi mógł się odwołać wyłącznie do Ps 106,30 [LXX] (Ps 107,30 $[\mathrm{BH}])$ jako tekstu źródłowego:

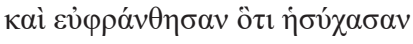

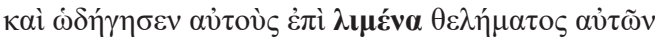

„i ucieszyli się, że się uspokoili,

i przywiódł ich do portu ich upragnienia”.
}

Fakt, że istnieje tylko jedno możliwe miejsce odniesienia, pozwala ów rzeczownik podnieść do poziomu aluzji, nie zaś potraktować jako echo intertekstualne. $Z$ echem mamy do czynienia wówczas, gdy przywoływany tekst - mimo zapożyczenia tego samego słownictwa, obrazu lub innych elementów tekstu źró-

przesuwaną na początek I w. przed Chr., spokojnie można przyjąć, że grecki tekst Księgi Daniela skomponowany został wcześniej niż Pierwszej Księgi Machabejskiej. Nawrot, Pierwsza Księga Machabejska. Rozdziaty 1,1-6,16, 144-150.

30 Pozostałe teksty 1 Ezd 5,53 oraz 4 Mch 7,3; 13,6.7 nie wchodzą w skład korpusu natchnionego, zaś teksty 2 Mch 12,6.9; 14,1 oraz Dz 27,8.12 zostały skomponowane już po powstaniu Pierwszej Księgi Machabejskiej. 
dłowego - nie wpływa decydująco na sens i znaczenie tekstu przywołującego ${ }^{31}$. Czytelnik rozpoznaje wówczas jedynie tekst wcześniejszy, zawarty w późniejszym, lecz nie czyni wysiłku, by modyfikować rozumienie drugiego w świetle pierwszego ${ }^{32}$. Otóż takie postępowanie nie może zachodzić w rozpatrywanym wersecie 1 Mch 15,4 właśnie z tej racji, że mamy tu do czynienia z odniesieniem do Ps 106,30 [LXX]. Zdobycie Jaffy i przekształcenie miasta w port ( $\lambda \iota \mu$ ív) było niewątpliwie jednym $\mathrm{z}$ wielkich sukcesów polityczno-militarnych Szymona. Werset $4 \mathrm{w}$ swej warstwie powierzchniowej nie wychodzi więc poza pole semantyczne geografii i historii. Tymczasem przywoływany psalm nie jest wersetem osadzonym w kontekście geograficzno-historycznym, lecz typowo teologicznym, w którym autor natchniony stwierdza, że tylko Bóg przywiedzie rozbitków do upragnionej przystani $(\lambda \mu \mu$ v $v)$, zaś wysiłki człowieka na nic się zdadzą ${ }^{33}$. Poza tym w Septuagincie znacznie częściej w podobnym kontekście miejsca, które

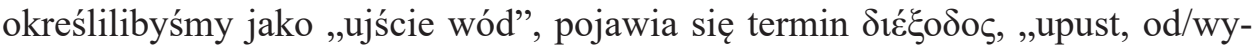
pływ", który jeszcze lepiej oddałby ideę miejsca, z którego można otworzyć się na świat, czyli morskiego wybrzeża. Odnajdziemy ten kontekst w Sdz 5,1734. Wydaje się zatem pewne, że skoro autor Pierwszej Księgi Machabejskiej świadomie użył terminu $\lambda \iota \mu \eta ́ v$, to nie możemy już mówić tu jedynie o intertekstualnym echu, lecz o wyraźnej aluzji do powszechnie znanego psalmu ${ }^{35}$.

Sam ów werset Ps 106,30 [LXX] (Ps 107,30 [BH]) należy do bliższego kontekstu wersetów 23-32, opisujących los żeglarzy wypływających w morze w celach handlowych (w. 23), doświadczających wielkich cudów Bożych pośród głębin, które nimi miotały i którym nie byli w stanie o własnych siłach się przeciwstawić (w. 24-27). Jedynym sposobem ratunku było wołanie do Pana, który odmienił sytuację (w. 28-29), co przyniosło wielką radość spowodowaną szczęśliwym powrotem do upragnionej przystani (w. 30). Powoduje to wdzięczność i publiczne wychwalanie Boga w świątyni (w. 31-32). Teologiczny akcent w wersecie 30 postawiony został na samo wybawiające działanie Boga w odpowiedzi na fiasko działań ludzkich i zasadniczą bezradność człowieka w walce

31 B.D. Sommer, A Prophet Reads Scripture: Allusion in Isaiah 40-66 (Stanford, CA: Stanford University Press 1998) 30-31.

32 G.D. Miller, „Intertextuality in Old Testament Research”, CurBR 9/3 (2010) 302.

33 J. Goldingay, Psalms (BCOTWP; Grand Rapids, MI: Baker Academic 2008) III, 256.

34 Także w: Lb 34,5.12; Joz 15,4.11; 16,3.8; 17,9; 18,12.14.19; 19,22.29, jako ustalone granice ciągnące się wzdłuż potoków lub rzek z zakończeniem na brzegu morza. Gwoli ścisłości należy jednak

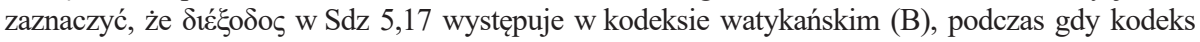

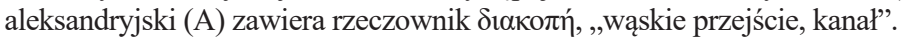

35 Tezę tę wzmacnia jeszcze fakt, że $\lambda$ uñ́v jako hapax w Ps 106,30 (LXX) odpowiada hebrajskiemu terminowi זָָז, ,,miasto przy porcie, miasto portowe” (Ps 107,30 [BH]), również jedynemu w Biblii Hebrajskiej; L. Koehler - W. Baumgartner - J.J. Stamm, Wielki stownik hebrajsko-polski i aramejsko-polski Starego Testamentu (PSBib; Warszawa: Vocatio 2008) 534; M. Dahood, Psalms. III. 101-150. A New Translation with Introduction and Commentary (AB 17A; New York: Doubleday 1970) 88-89. 
z morskim żywiołem. Warto podkreślić, że zwrotu „przywiódł ich do portu ich upragnienia" nie należy rozumieć w sensie cudu zakładającego całkowity brak ludzkiego działania, koniecznego wręcz, by dopłynąć do portu. Hagiograf chce jedynie podkreślić, że mogło się to dokonać wyłącznie dzięki działaniu Bożemu na innym poziomie, które jednak odegrało decydującą rolę w szczęśliwym zakończeniu wyprawy. Nie bez znaczenia jest także ogólna teologia relacji Boga do wód, których odmęty widziane są często jako Jego główny wróg (Ps 64,8 [LXX]; 65,8 [BH]; 73,13-14 [LXX]; 74,13-14 [BH]), lecz nad którymi On całkowicie panuje, czego paradygmatem jest osuszenie wód Morza Czerwonego (Ps 76,17-20 [LXX]; 77,17-20 [BH]; 77,13 [LXX]; 78,13 [BH]; 105,6-12 [LXX]; 106,6-12 [BH] $)^{36}$. Chcąc wzmocnić swą aluzję do Ps 106,30 [LXX]; Ps 107,30 [BH], autor Pierwszej Księgi Machabejskiej wykorzystał zapewne także porównanie nieprzyjaciół Izraela do wzbierających wokół wód, piętrzących się po to, by zalać ziemię narodu wybranego (Iz 8,5-8; 17,12-14; Ha 3,15; Ps 45,3-4 [LXX]; Ps 46,3-4[BH] $)^{37}$. W ten sposób autor buduje całościową teologię danego wydarzenia, możliwą do odkrycia przez czytelnika poszukującego aluzji intertekstualnej.

To przywołanie wcześniejszych tekstów kanonicznych wpływa na nowe zrozumienie sensu wersetu 1 Mch 14,5, biegnące w tym samym kierunku, co poprzedzające je aluzje. Otóż czytelne i oczywiste jest to, że Bóg nie sprzeciwia się zdobywaniu kolejnych ziem przez Szymona, ponieważ z dawien dawna były to ziemie przyrzeczone przodkom Izraela. Poza tym nieunikniona walka z pogańskimi nieprzyjaciółmi w obronie praw do własnej ziemi od zawsze spotyka się ze wsparciem z Jego strony. Tymczasem Bóg sprzeciwia się stanowczo przypisywaniu sobie przez ludzi tego, co czyni wyłącznie On, ponieważ tylko On jest sprawcą wszelkich ludzkich sukcesów. W tym kontekście autor Pierwszej Księgi Machabejskiej sugeruje niemożliwe do zaakceptowania przekonanie arcykapłana o własnych możliwościach i umiejętnościach jako właściwym źródle jego dotychczasowych sukcesów - z pominięciem Boga.

\section{c) terminy nietworzące zwrotu}

a) Aż cztery słowa, tym razem niezespolone w jednym zwrocie, również mogą wpłynąć na zaistnienie aluzji intertekstualnej. Odnoszą one do konkretnych tekstów biblijnych, pod warunkiem jednak, że wynikła z nich teologia jest

36 Rekapitulacja biblijnej teologii konfliktu Boga z wodami, jako Jego nieprzyjaciółmi, J.H. Walton J.H. Walton, Demons and Spirits in Biblical Theology. Reading the Biblical Text in Its Cultural and Literary Context (Eugene, OR: Cascade Books 2019) 99-105.

37 Szersze omówienie problematyki J. Day, God's Conflict with the Dragon and the Sea. Echoes of a Canaanite Myth in the Old Testament (Cambridge - London: Cambridge University Press 1988) 93-94, 101-109, 120. 
w pełni spójna z całością tekstu przywoływanego. Zasada jest prosta: im więcej terminów wspólnych wersetom obydwu tekstów, tym większe prawdopodobieństwo zaistnienia aluzji. W 1 Mch 14,5 czytelnik zauważy więc aluzję w zwrocie $\pi \tilde{\alpha} \sigma \alpha \dot{\eta} \delta$ ó $\xi \alpha$, „cała chwała”, połączonym z dwoma czasownikami: $\lambda \alpha \mu \beta \alpha ́ v \omega$,

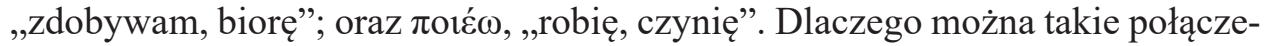
nie odkryć i zinterpretować? Wynika to z sensu zdania, w którym jeden bohater (Szymon), scharakteryzowany konkretnym zwrotem dopełnieniowym ( $\pi \tilde{\alpha} \sigma \alpha \dot{\eta}$ $\delta o ́ \xi \alpha$ ), definiuje swe postępowanie dwoma czasownikami formalnie stojącymi wobec siebie w związku współrzędnym, czyli na równym poziomie przyporządkowania do osoby $(\lambda \alpha \mu \beta \alpha ́ v \omega+\pi$ oเé $\omega)$. Można to ukazać za pomocą poniższego schematu.

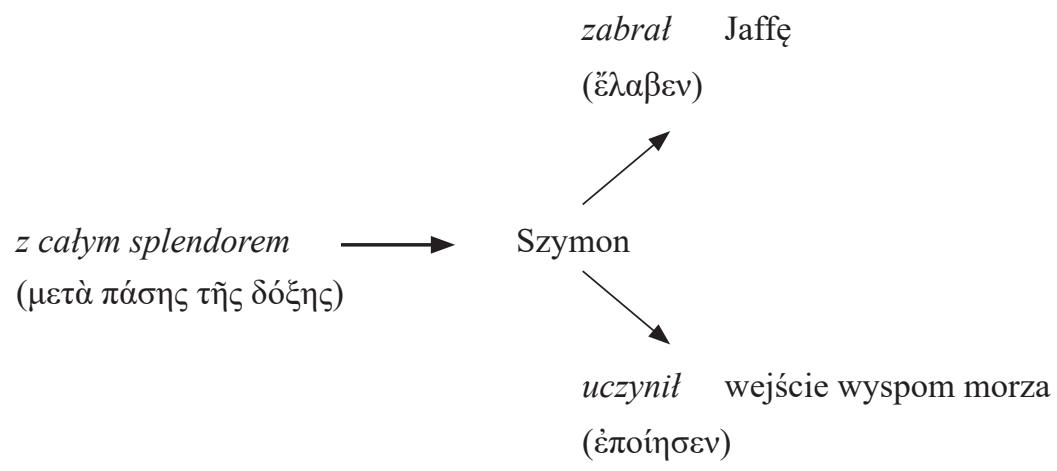

W powyższym związku semantycznym chwała Szymona towarzyszyła $z a$ garnięciu miasta i uczynieniu z niego portu dla potrzeb kraju oraz prowadzenia handlu z krajami zamorskimi. W taki sposób ocenili działania arcykapłana jego rodacy. Otóż jedynym biblijnym wersetem zawierającym wszystkie terminy:

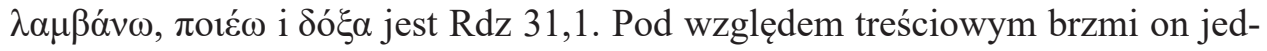
nak zrazu całkowicie obco w stosunku do prezentowanego wersetu Pierwszej Księgi Machabejskiej:

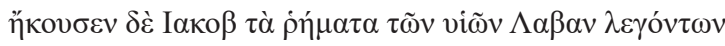

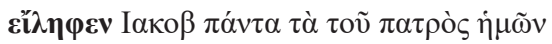

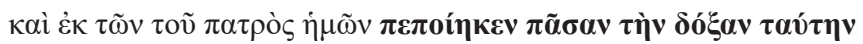

„usłyszał Jakub słowa synów Labana mówiących:

zabral Jakub wszystkie dobra naszego ojca

i z wszystkiego [co należy do] ojca naszego uczynil cały swój splendor”.

Omawiany werset należy do kontekstu Rdz 31,1-16, czyli wersetów relacjonujących decyzję Jakuba, by uciec spod kurateli swego wuja, zwłaszcza że jego 
synowie niesprawiedliwie oceniając jego zachowanie, zaczęli mu zazdrościć majątku, którego się dorobił ${ }^{38}$. Egzegeci zwracają uwagę, że cały passus zestawia konfrontacyjnie to, co w pierwszym oglądzie narzuca się odbiorcy w planie fabularnym opowieści, a co tak naprawdę jest mniemaniem fałszywym (w. 1-2.5a) w zestawieniu z rzeczywistą sytuacją, która jest przedstawiona przez autora Księgi Rodzaju jako efekt działania Bożego (w. 3-4.5b.6-16) ${ }^{39}$.

Wpierw zatem zauważyć trzeba zaistnienie tego samego związku wyrazowego i funkcji, które poszczególne terminy pełnią w przywoływanym wersecie, choć tym razem na zasadzie odwrotności.

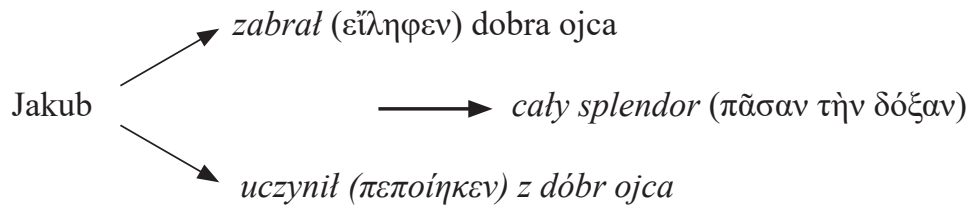

Na splendor/sławę Jakuba złożyło się suponowane przez synów zagarnięcie majątku Labana i uczynienie z niego podstawy własnych dóbr, stanowiących część osobistej dumy Jakuba i powód do ich zazdrości ${ }^{40}$. Kluczowe znaczenie aluzji, którą w 1 Mch 14,5 zastosował hagiograf, leży właśnie w owej odwrotności sytuacji, na którą składają się zarówno konkretne posunięcia obu biblijnych bohaterów (Jakuba i Szymona), jak i kontekst wydarzeń. Jakub, oszukiwany przez wuja i kuzynów (Rdz 31,7a), uczciwie i od podstaw buduje swą materialną pomyślność poprzez pracę, której patronuje Bóg (Rdz 31,7b.12-13). Szymon udając dbałość o kraj, wykorzystuje swych rodaków i siłę armii powstańczej (1 Mch 13,58), aby zdobyć Jaffę i uczynić z niej port. Jego intencje i cele wydają się jednak bardzo egoistyczne i interesowne. Czyni to bowiem ostatecznie po to, by chwałę, którą się cieszył u ludu, jeszcze zwiększyć. Bóg jednak już temu patronować nie będzie. Nie można też pominąć faktu, że w całym wersecie Rdz 31,1 synowie Labana błędnie interpretują to, co czyni Jakub ${ }^{41}$. W taki sam sposób w Pierwszej Księdze Machabejskiej zwiedziony naród błędnie interpretuje posunięcia swego arcykapłana. Synowie Labana krzywdzili kuzyna, zarzucając mu nieuczciwość, podczas gdy Jakub był w rzeczywistości człowie-

38 A.E. Steinmann, Genesis. An Introduction and Commentary (TOTC; Nottingham: Inter Varsity Press Academic 2019) 294.

39 J. Lemański, Księga Rodzaju. Rozdzialy 11,27-36,43. Wstęp - przekład z oryginatu - komentarz (NKB.ST 1/2; Częstochowa: Edycja Świętego Pawła 2014) 797-798.

40 Tę samą myśl zawierają opisy sławy m.in. Jozafata (2 Krn 18,1), Ezechiasza (2 Krn 32,27), perskiego króla Aswerusa (Est 1,4), Hamana (Est 5,1), budowanej na bogactwie materialnym. 1 Mch 10,58.60 oraz 11,6 wspominają o przepychu materialnym.

$41 \quad$ K.A. Mathews, Genesis 11:27 - 50:26. An Exegetical and Theological Exposition of Holy Scripture (NAC 1B; Nashville, TN: Broadman \& Holman 2005) 510-511. 
kiem pracowitym. Tymczasem w Pierwszej Księdze Machabejskiej mamy sytuację odwrotną - wódz powstania Machabeuszy krzywdzi poddanych, ponieważ umiejętnie nimi manipuluje i pozwala im wierzyć w swoją uczciwość i zatroskanie o los narodu wybranego. Faktycznie zaś Szymon całkowicie zapomniał o Bogu, przypisując sobie kolejne sukcesy i pławiąc się coraz bardziej we własnej wielkości.

$\beta)$ Kolejną, tego samego typu aluzją jest także zestawienie terminów cíoooos,

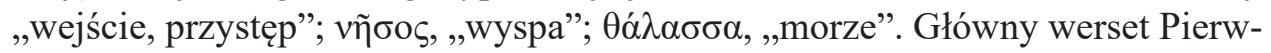
szej Księgi Machabejskiej stwierdza, że zwycięstwo Szymona pozwoliło uczynić

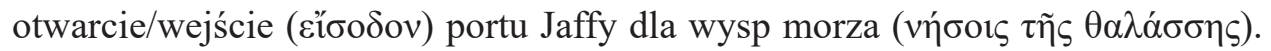
Wszystkie trzy rzeczowniki odnaleźć można w prorockim tekście Ez 27,3:

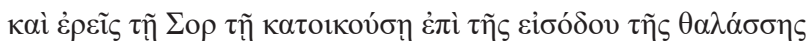

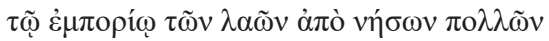

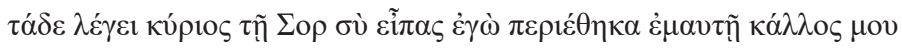

„powiesz Tyrowi mieszkającemu przy wejściu morza,

rynkowi ludów z wielu wysp,

tak mówi Pan Tyrowi: Ty mówisz: ja przystroiłem siebie moim pięknem”.

Wersety Ez 37,3b-36 zawierają zapowiedź wyroku Bożego na butny Tyr,

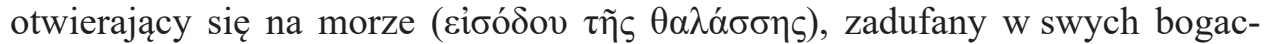

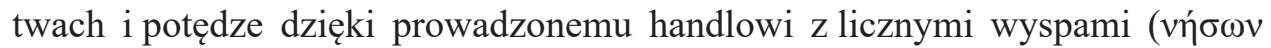
$\pi 0 \lambda \lambda \tilde{\omega} v)$. Cały splendor wyspy buduje się na materialnym bogactwie, służącym podkreślaniu własnej wartości, o czym świadczy długi opis świetności Tyru (Ez 27,4-26a.27a). W dalszej części mowy prorok stwierdza jednak, że wszystko zginie na dnie morza, a klęska wyspy będzie całkowita i nieodwołalna (Ez 27,27b-36) ${ }^{42}$. W kolejnym passusie Ez 28,1-6 opisana została rzeczywista przyczyna upadku miasta, którą jest niepohamowana pycha króla Tyru i jego mieszkańców. Zabezpieczyli oni siebie przed nieszczęściem zarówno ogromnymi bogactwami, jak i fortyfikacjami nie do zdobycia i w tym - tylko w tym - całkowicie pokładali nadzieję na dalszy szczęśliwy los.

Wydaje się, że nie ma lepszego odniesienia dla zarozumiałości Szymona niż to zadufanie w sobie władcy Tyru. Godnym podkreślenia jest także fakt, że autor Pierwszej Księgi Machabejskiej skorzystał wpierw z porównania arcykapłana do skądinąd niewielkiego, choć niezwykle zasobnego miasta, którego mieszkańcy uważali się za swoisty pępek świata. To poczucie zyskali dzięki budowaniu relacji handlowych, gromadzeniu bogactw, wzmocnieniu obronności oraz szerokich

42 D.I. Block, The Book of Ezekiel. Chapters 25-48 (NICOT; Grand Rapids, MI - Cambridge: Eerdmans 1998) 54-87. 
stosunkach dyplomatycznych. Wszystko to zdawało się zapewniać spokój i trwałość rządów kolejnych władców miasta. Następnie hagiograf wykorzystał zdanie, które rozpoczyna cały opis bogactwa, doskonałości i zmyślności mieszkańców Tyru i otwiera całą sekwencję opisującą wzrost siły, sławy, świetności i wspaniałości miasta. Poprzez zastosowanie konkretnej aluzji terminologicznej los Tyru stanowi znakomity punkt odniesienia do życia i panowania Szymona. Obydwa wspomniane wyżej nawiązania są wielce znaczące. Dzięki nim autor, nie mówiąc tego wprost, przekazuje czytelnikowi, że Szymon nie jest nikim wielkim, by zagrozić ówczesnym potęgom politycznym i militarnym, zachowuje się jednak jak suwerenny władca. Ponadto, poprzez zastosowanie licznych aluzji, zawoalowana krytyka intencji towarzyszących posunięciom arcykapłana następuje już od początku opisu jego wzrastającej świetności i splendoru (1 Mch 14,6-15) ${ }^{43}$. Ostrość tej krytyki dojdzie maksimum w szczytowym momencie pychy wodza narodu, jakim stanie się dekret ludu chwalący jego dokonania (1 Mch 14,27-45) i pozwolenie na nieograniczoną władz nad krajem (1 Mch 14,46-49). Dlatego niesławny koniec obu - zarówno władcy Tyru, jak i żydowskiego arcykapłana - będzie podobny: zniszczenie i śmierć (Ez 27,27-36; 1 Mch 16,15-16).

Jeśli pokusić się o podanie właściwego teologicznego sensu wersetu, mogłoby ono wyglądać następująco:

\begin{tabular}{|l|l|}
\hline \multicolumn{1}{|c|}{ werset $\mathbf{1 4 , 5}$ w księdze } & \multicolumn{1}{c|}{ ukryty sens teologiczny } \\
\hline Z catym swym splendorem & $\begin{array}{l}\text { Z ogromem swej pychy - budowanej na sukcesach } \\
\text { militarnych, popularności i bogactwie materialnym }-\end{array}$ \\
\hline zdobyt Jaffę na port & $\begin{array}{l}\text { pominąt Boga, realizując interesy własne i swego } \\
\text { rodu po to, }\end{array}$ \\
\hline i uczynit wejście dla wysp morza & $\begin{array}{l}\text { by wzmacniać swe panowanie, zwłaszcza poprzez } \\
\text { gromadzenie dóbr materialnych i uznanie spoteczne. }\end{array}$ \\
\hline
\end{tabular}

Obok odkrywania ukrytych motywacji postępowania Szymona hagiograf akcentuje również błędne pojmowanie posunięć arcykapłana przez lud, który bezrefleksyjnie popiera działania swojego przywódcy, będąc przekonanym, że służą one dobru całego kraju. Prawdziwe dobro polega jednak nie na dostatku materialnym i bezpieczeństwie, lecz na wierności Bożemu prawu, od którego Szymon - mimo oficjalnej dbałości o świątynię, kult i zewnętrzny kształt przepisów prawa - w rzeczywistości odszedł. Im więcej zamożności, władzy, popularności i poparcia, tym mniej zważania na wierność Bogu, od którego przecież wszystko pochodzi i od którego życie ludzkie zależy całkowicie i w każdym momencie.

43 Nawrot, Pierwsza Księga Machabejska. Rozdziaty 6,17-16,24, 895-911. 


\section{Podsumowanie}

Zastosowana przez autora Pierwszej Księgo Machabejskiej metoda tworzenia centonu jako znanego i praktykowanego w starożytności gatunku literackiego, pozwala mu na różne sposoby budować aluzje literackie. Odsłaniają one rzeczywisty sens opisywanych wydarzeń, ujawniony i odszyfrowywany w świetle teologii autora. Z kolei czytelnik, odkrywając właściwą intencję hagiografa, już samodzielnie, jako adresat ukrytych treści, poprawnie ocenia postępowanie poszczególnych bohaterów. Ten zabieg sprawia, że odbiorca tekstu hagiografa widzi wydarzenia historyczne tak, jak są one widziane oczami samego Boga. Tak jakby sam widział Boży plan działania w historii Izraela i miejsce w nim konkretnych osób, w tym szczególnie Szymona. Centon wydał się zapewne autorowi najlepszym środkiem przekazu, ponieważ łączy w sobie poszczególne frazy z wcześniejszych, świętych dla Izraela ksiąg i buduje przez to ważne dla autora przesłanie teologiczne. Poprawność jego odczytania przez czytelnika gwarantowana jest całkowitą zgodnością przywoływanych wersetów z tymi tworzonymi przez hagiografa dzięki użyciu terminów zapożyczonych od poprzedników. Zgodność ta wynika wpierw z ich spójności treściowej, a następnie nośności teologicznej.

Z punktu widzenia czytelnika spójność teologiczna ma dwa zasadnicze cele:

a) odczytanie poprawności interpretacji wydarzeń historycznych i celu teologicznego hagiografa używającego intencjonalnych aluzji literackich;

b) właściwe odczytanie treści powierzchniowej, mogącej dla niezorientowanego czytelnika brzmieć zrazu całkowicie odwrotnie.

W przypadku autora Pierwszej Księgi Machabejskiej zasadnicze znaczenie ma literacki kontekst, który decyduje o doborze aluzji. To waga i autorytet pierwowzoru wpływa na teologiczną nośność wersetów hagiografa i wzbogaca je swoją formą i treścią, przyczyniając się istotnie do skonstruowania nowego orędzia i do siły przekonania piszącego.

\section{Literatura:}

Bailly, A., Dictionnaire grec-français, wyd. 26 (Paris: Hachette 1963).

Ben-Porat, Z., „The Poetics of Literary Allusion”, Poetics and Theory of Literature - A Journal for Descriptive Poetics and Theory of Literature 1 (1976) 105-128.

Block, D.I., The Book of Ezekiel. Chapters 25-48 (New International Commentary on the Old Testament; Grand Rapids, MI - Cambridge: Eerdmans 1998).

Cullhed, S.S., Proba the Prophet. The Christian Virgilian Cento of Faltonia Betitia Proba (Leiden Boston, MA: Brill 2015). 
Dahood, M., Psalms. III. 101-150. A New Translation with Introduction and Commentary (Anchor Bible 17A; New York: Doubleday 1970).

Day, J., God's Conflict with the Dragon and the Sea. Echoes of a Canaanite Myth in the Old Testament (Cambridge - London: Cambridge University Press 1988).

Głowiński, M., „O intertekstualności”, Pamiętnik Literacki 77/4 (1986) 75-100.

Goldingay, J., Psalms (Baker Commentary on the Old Testament Wisdom and Psalms; Grand Rapids, MI: Baker Academic 2008) III.

Górski, K., „Aluzja literacka”, Problemy teorii literatury (red. H. Markiewicz) (Wrocław - Warszawa-Kraków: Ossolineum 1987) I, 314-338.

Grzenia, J., „Cytat a aluzja literacka”, Z problemów współczesnego języka polskiego (red. A. Wilkoń - J. Warchala) (Katowice: Uniwersytet Śląski 1993) 107-117.

Grzenia, J., „Funkcje aluzji literackiej na przykładzie poezji Jarosława Marka Rymkiewicza”, Język Artystyczny 7 (1990) 79-92.

Hartman, L.F. - Di Lella, A.A., The Book of Daniel. A New Translation with Introduction and Commentary (Anchor Bible 23; New York et al.: Doubleday 2005).

Hermerén, G., „Intencja a interpretacja w badaniach literackich”, Pamiętnik Literacki 68/4 (1977) 353-381.

Koehler, L. - Baumgartner, W. - Stamm, J.J. (red.), Wielki stownik hebrajsko-polski i aramejsko-polski Starego Testamentu (Prymasowska Seria Biblijna; Warszawa: Vocatio 2008).

Lamarcchia, R., „Metro e ritmo nella Medea di Osidio Geta”, Studi italiani di filologia classica 30 (1958) 175-206.

Lemański, J., Księga Rodzaju. Rozdziały 11,27-36,43. Wstęp - przekład z oryginału - komentarz (Nowy Komentarz Biblijny. Stary Testament 1/2; Częstochowa; Edycja Świętego Pawła 2014).

Mathews, K.A., Genesis 11:27 - 50:26. An Exegetical and Theological Exposition of Holy Scripture (New American Commentary 1B; Nashville, TN: Broadman \& Holman 2005).

McGill, S., Virgil Recomposed. The Mythological and Secular Centos in Antiquity (Oxford - New York: Oxford University Press 2005).

McLay, R.T., "The Old Greek Translation of Daniel IV-VI and the Formation of the Book of Daniel", Vetus Testamentum 55/3 (2005) 304-323.

Miller, G.D., "Intertextuality in Old Testament Research", Currents in Biblical Research 9/3 (2010) 283-309.

Miller, S.R., Daniel. An Exegetical and Theological Exposition of Holy Scripture (New American Commentary 18; Nashville, TN: Broadman \& Holman 1994).

Nawrot, J., „Dlaczego oni zwyciężają? Teologiczna ocena judejskiej kampanii Antiocha V Eupatora w 1 Mch 6,47-54", Studia Gnesnensia 31 (2017) 85-104.

Nawrot, J., Pierwsza Księga Machabejska. Rozdziały 1,1-6,16 (Nowy Komentarz Biblijny. Stary Testament 14/1; Częstochowa: Edycja Świętego Pawła 2016).

Nawrot, J., Pierwsza Księa Machabejska. Rozdziały 6,17-16,24. (Nowy Komentarz Biblijny. Stary Testament 14/2; Częstochowa: Edycja Świętego Pawła 2020).

Okáčová, M., „Centones: Recycled Art Or The Embodiment of Absolute Intertextuality?”, http://www.kakanien.ac.at/beitr/graeca_latina/MOkacova1.pdf [dostęp: 18.06.2020].

Parchem, M., Księga Daniela (Nowy Komentarz Biblijny. Stary Testament 26; Częstochowa: Edycja Świętego Pawła 2008). 
Phillips, J., Exploring the Book of Daniel. An Expository Commentary (The John Phillips Commentary Series; Grand Rapids, MI: Kregel Publications 2004).

Podsiad, A. - Więckowski, Z. (red.), Mały słownik terminów i pojęć filozoficznych dla studiujacych filozofię chrześcijańska (Warszawa: Instytut Wydawniczy Pax 1985).

Przybyszewski, S., „Semantyczna i syntaktyczna analiza leksemu aluzja”, Prace Językoznawcze 10 (2008) 187-200.

Pucci, J.M., The Full-Knowing Reader. Allusion and the Power of the Reader in the Western Literary Tradition (New Haven, CT: Yale University Press 1998).

Rondholz, A., The Versatile Needle. Hosidius Geta's Cento "Medea" and Its Tradition (Berlin - Boston, MA: De Gruyter 2012).

Sommer, B.D., A Prophet Reads Scripture. Allusion in Isaiah 40-66 (Stanford, CA: Stanford University Press 1998).

Steinmann, A.E., Genesis. An Introduction and Commentary (Tyndale Old Testament Commentaries; Nottingham: Inter Varsity Press Academic 2019).

Szajnert, D., „Intencja i interpretacja”, Pamiętnik Literacki 91/1 (2000) 7-42.

Walton, J.H. - Walton, J.H., Demons and Spirits in Biblical Theology. Reading the Biblical Text in Its Cultural and Literary Context (Eugene, OR: Cascade Books 2019).

Wojciechowski, M. (tł. i red.), Apokryfy z Biblii greckiej. 3 i 4 Księga Machabejska, 3 Księga Ezdrasza, oraz Psalm 151 i Modlitwa Manassesa (Rozprawy i Studia Biblijne 8; Warszawa: Vocatio 2001). 